\title{
Heat shock protein (hsp70) expression and thermal tolerance in sublethally heat-shocked eastern oysters Crassostrea virginica infected with the parasite Perkinsus marinus
}

\author{
V. G. Encomio ${ }^{1}$, F.-L. E. $\mathrm{Chu}^{2, *}$ \\ ${ }^{1}$ Florida Gulf Coast University, 10501 FGCU Blvd. South Fort Myers, Florida 33965, USA \\ ${ }^{2}$ Virginia Institute of Marine Science, 1208 Greate Road Gloucester Point, Virginia 23062, USA
}

\begin{abstract}
To investigate whether sublethal heat shock protects Perkinsus marinus (Dermo)infected oysters Crassostrea virginica from lethal heat stress, and the effects of $P$. marinus infection on sublethal heat shock response, oysters were first experimentally challenged with $P$. marinus. Then, when infections in oysters progressed to moderate levels (parasite burden $=10^{4}$ to $10^{5}$ cells g $^{-1}$ wet tissue weight), oysters were treated with a sublethal heat shock at $40^{\circ} \mathrm{C}$ for $1 \mathrm{~h}$ (heat shock + Dermo challenge). Other treatment groups included heat-shocked, unchallenged (non- $P$. marinus challenged) oysters and non-heat-shocked, $P$. marinus-challenged and -unchallenged oysters. Thermal tolerance was compared among these treatments by administering a lethal heat treatment at $44^{\circ} \mathrm{C}$ for $1 \mathrm{~h}, 7 \mathrm{~d}$ after sublethal heat shock. Sublethal heat shock enhanced survival to lethal heat treatment in both P. marinus-challenged and -unchallenged oysters. Although levels of hsp70 isoforms (hsp69 and hsp72) did not vary significantly by heat shock or infection with $P$. marinus, responses due to these treatments were apparent when comparing hsp70 levels within infected and uninfected oysters. Infection enhanced expression of hsp69, regardless of whether oysters were heat shocked or not. In uninfected oysters, hsp72 increased due to heat shock 2 and $7 \mathrm{~d}$ post heat shock. Overall, this study demonstrates that heat shock can improve survival in oysters, even in oysters infected with P. marinus. Expression of hsp70 varied among isoforms after sublethal and lethal heat shocks and in infected and uninfected oysters. The heat shock response was not negatively affected by $P$. marinus infection.
\end{abstract}

KEY WORDS: Crassostrea virginica $\cdot$ Heat shock protein $\cdot$ Hsp70 $\cdot$ Perkinsus marinus $\cdot$ Thermal tolerance

\section{INTRODUCTION}

Dermo disease, caused by the parasitic protozoan Perkinsus marinus, has devastated populations of the eastern oyster Crassostrea virginica along the Atlantic and Gulf of Mexico coasts of the United States since the 1950s (Andrews 1988). The disease is particularly problematic because $P$. marinus persists over a broad range of temperatures and salinities (Chu \& LaPeyre 1993, Burreson et al. 1994). Mortalities caused by $P$. marinus increase at temperatures $>25^{\circ} \mathrm{C}$, as the parasite proliferates rapidly, causing extensive damage to host cells and tissues (Andrews 1965, Fisher et al. 1992, La Peyre 1996). Although eastern oysters can tolerate high temperatures, the interactive effect of disease and thermal stress may be intense, leading to death. Dermo-resistant oysters have been identified and selectively bred, but mechanisms contributing to Dermo resistance are currently unknown (Maers 1993, Calvo et al. 2003, Encomio et al. 2005). Mechanisms such as heat shock proteins, which provide protection for cells and tissues, may be important in counteracting the dual stresses of temperature and disease in oysters. 
Heat shock proteins act as molecular chaperones, facilitating proper folding, assembly and intracellular transport of proteins. They are highly conserved, occurring in all organisms (Feder \& Hofmann 1999). Heat shock proteins in the $70 \mathrm{kDa}$ family are the most commonly expressed heat shock proteins in response to stress (Lindquist 1986). Their activity aids in protecting organisms from thermal or other stress-induced damage (Lindquist \& Craig 1988, Morimoto et al. 1990, Gething \& Sambrook 1992, Gupta \& Golding 1993). Enhanced tolerance to stress, resulting in improved survival and condition, has been correlated with increased levels of heat shock proteins (Bosch et al. 1988, Sanders 1988).

In a wide variety of organisms, thermal tolerance can be enhanced experimentally via exposure to a sublethal heat shock (Lindquist 1986). Over-expression of heat shock proteins is associated with this phenomenon, known as acquired or induced thermal tolerance (Sanchez \& Lindquist 1990). Furthermore, application of sublethal heat shock has been shown to increase resistance to other stressors besides high temperature. For example, sublethal heat shock increased cadmium resistance in mussels (Tedengren et al. 1999). Increased expression of heat shock proteins due to sublethal heat shock and the acquisition of enhanced tolerance to stress, be it thermal or otherwise, are distinct characteristics of the heat shock response.

Oysters are estuarine species that are impacted by various stressors (e.g. diseases, hypoxia, and toxicants or pollutants) and wide fluctuations in temperature. An understanding of the stress response in oysters may offer insights on how to improve their survival and production. The heat shock response has been studied in several species of oysters (Shamseldin et al. 1997, Clegg et al. 1998, Piano et al. 2002, Boutet et al. 2003, Hamdoun et al. 2003, Brown et al. 2004). Increased levels of heat shock proteins were associated with improved thermal tolerance in Pacific oysters (Clegg et al. 1998). Levels of hsp70 increased after heat shock treatments of eastern oyster hemocytes. Tirard et al. (1995) proposed a potential mechanism by which the immune function in oysters could be improved. However, no study has determined whether sublethal heat shock would protect Perkinsus marinus-infected oysters from lethal thermal stress and whether the heat shock response of oysters is affected by $P$. marinus infection.

The objectives of the present study were (1) to determine whether sublethal heat shock improves the survival of Perkinsus marinus-infected and -uninfected oysters to later lethal thermal stress and (2) to characterize the hsp70 expression in $P$. marinusinfected and -uninfected oysters after sublethal and lethal heat shocks.

\section{MATERIALS AND METHODS}

Oysters. Adult eastern oysters Crassostrea virginica originated from the Damariscotta River, Maine (Pemaquid Oyster Company), where oysters are rarely infected by Perkinsus marinus (Kleinshuster \& Parent 1995). Oysters shipped from Maine were screened initially for $P$. marinus infection $(\mathrm{n}=25)$ prior to experiments following Ray's (1966) method. Results were negative. Oysters were acclimated to and then maintained at temperatures of 20 to $22^{\circ} \mathrm{C}$ and salinities of 15 to 18 for $2 \mathrm{wk}$, until experiments were performed.

Experiments. Experimental infections with Perkinsus marinus: Oysters were challenged with $P$. marinus meronts $\left(\sim 10^{6}\right.$ cells oyster $\left.{ }^{-1}\right)$ freshly isolated from infected oyster tissues, as described by Chu \& Volety (1997). Briefly, infected oyster tissues were mechanically homogenized in $0.22 \mu \mathrm{m}$ filtered York River water (YRW). The suspension was then passed through a series of filters $(100,50,35$ and $20 \mu \mathrm{m}$ mesh sizes). The filtrate was then centrifuged and washed several times to remove any remaining tissue debris. Meronts were counted in a hemacytometer, and the cell density was

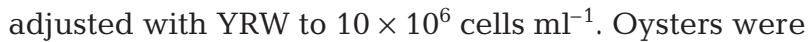
inoculated with $100 \mu \mathrm{l}\left(\cong 1 \times 10^{6}\right.$ cells oyster $\left.^{-1}\right)$ of the meront suspension. Inoculation was performed by shell cavity injection through a notch made on the dorsal axis of the oyster shell. Non-challenged control oysters were inoculated with a sham treatment of $100 \mu \mathrm{l}$ YRW (Chu \& Volety 1997). To monitor progression of infection in $P$. marinus-challenged oysters, 3 oysters from 2 tanks (24 oysters per tank) were sampled ( $\mathrm{n}=6$ oysters per sampling) weekly for $P$. marinus analysis. $P$. marinus infections were assessed by the body burden enumeration technique (Choi et al. 1989, Bushek et al. 1994). Moderate to high densities of infection have typically been obtained $60 \mathrm{~d}$ postchallenge with $2.5 \times 10^{4}$ cells (meront stage) per oyster (Chu \& Volety 1997).

Sublethal and lethal heat shock treatments: When Perkinsus marinus (Dermo)-challenged oysters attained moderate to high infections $\left(\sim 10^{4}\right.$ to $10^{5}$ cells $\mathrm{g}^{-1}$ wet tissue weight), $60 \mathrm{~d}$ after $P$. marinus inoculation, both $P$. marinus-challenged and -unchallenged oysters were exposed to a sublethal heat shock $\left(40^{\circ} \mathrm{C}, 1 \mathrm{~h}\right)$, to enhance hsp70 expression and induce thermal tolerance. This heat shock temperature was chosen because heat shocks up to $42^{\circ} \mathrm{C}$ for $1 \mathrm{~h}$ did not kill oysters (Encomio 2004, Encomio \& Chu 2004). In eastern oysters, after a $1 \mathrm{~h}$ heat shock at $37^{\circ} \mathrm{C}$, total hsp 70 increased 7 and $8 \mathrm{~d}$ post sublethal heat shock and remained elevated up to 14-15 d after heat shock (Encomio 2004).

Four experimental treatments were arranged in a $2 \times$ 2 factorial design, with 3 to 4 replicate holding tanks 
for each of the treatments (18 to 20 oysters per tank). The 4 treatment groups were: (1) sublethal heatshocked, Dermo-challenged oysters (HS + DC); (2) non-sublethal heat-shocked, Dermo-challenged oysters (N + DC); (3) sublethal heat-shocked, unchallenged oysters (HS + UC); and (4) non-sublethal heatshocked, unchallenged oysters $(\mathrm{N}+\mathrm{UC})$. After sublethal heat shock at $40^{\circ} \mathrm{C}$ for $1 \mathrm{~h}, 3$ oysters from each replicate tank of each treatment group ( $\mathrm{n}=$ a total of 9 to 12 oysters per treatment) were sampled at 0 (immediately after sublethal heat shock), 2 and $7 \mathrm{~d}$ after sublethal heat shock for analysis of hsp70 and Perkinsus marinus infection.

After oysters were sampled on Day 7, all treatment groups were subjected to a lethal heat treatment (LHT) of $44^{\circ} \mathrm{C}$ for $1 \mathrm{~h}$, and mortality was monitored for $1 \mathrm{wk}$. The chosen temperature of $44^{\circ} \mathrm{C}$ as the LHT was based on our previous observation that mortality occurred in oysters after heat shock at 43 to $45^{\circ} \mathrm{C}$ for $1 \mathrm{~h}$ (Encomio 2004, Encomio \& Chu 2004). The number of oysters remaining in each tank at the time of the LHT ranged between 8 and 11 individuals per tank. Surviving oysters were sampled for analysis of hsp70 and Perkinsus marinus infection $1 \mathrm{wk}$ after LHT (14 d after sublethal HS).

SDS-PAGE and Western blot detection of hsp70: Gill tissues from oysters were excised, freeze-dried for $48 \mathrm{~h}$, weighed and stored at $-80^{\circ} \mathrm{C}$. Gill tissues were then homogenized on ice in $2 \mathrm{ml}$ of buffer $(66 \mathrm{mM}$ Tris $\mathrm{pH} 7.2,3 \%$ Igepal CA-630, $0.1 \mathrm{mM}$ phenylmethanesulfonyl fluoride [PMSF]). The homogenate was centrifuged at $10000 \times g$ for $30 \mathrm{~min}$ at $4^{\circ} \mathrm{C}$, and the supernatant (gill extract) was collected. Total protein concentration was determined using a modified version of the Lowry assay (Bio-Rad DC Protein Assay; Lowry et al. 1951).

A portion of the gill extract was diluted 1:2 in Laemmli sample buffer (BioRad) for SDS-PAGE. Samples were boiled for $5 \mathrm{~min}$, and $10 \mu \mathrm{g}$ of total protein per sample were electrophoresed on $8 \%$ polyacrylamide gels (150 V, $90 \mathrm{~min})$. In addition to experimental gill samples, $10 \mu \mathrm{g}$ protein from a 'reference sample' of gill tissue, obtained by exposing an oyster to a $1 \mathrm{~h}$ heat shock at $40^{\circ} \mathrm{C}$, was run on every gel. Separated proteins were then transferred onto nitrocellulose membrane at $100 \mathrm{~V}$ for $1 \mathrm{~h}$ in transfer buffer (192 mM glycine, $24 \mathrm{mM}$ Tris base and $20 \%$ methanol). After transfer, nitrocellulose blots were processed for immunodetection of hsp70 isoforms. The blot was blocked with $5 \%$ bovine serum albumin (BSA) in Tween-Tris-buffered saline (TTBS; 0.05\% Tween, $30 \mathrm{mM} \mathrm{NaCl}, 24 \mathrm{mM}$ Tris pH 7.5) for $30 \mathrm{~min}$ followed by 2 washes in Tris-buffered saline (TBS; $30 \mathrm{mM} \mathrm{NaCl}$, $24 \mathrm{mM}$ Tris pH 7.5) for 5 min each. Primary monoclonal antibody against hsp70 (Clone 3A3; Catalog MA3-006,
Affinity Bioreagents) was applied for 90 min (1:5000 dilution), followed by two 5 min washes with TBS. A secondary antibody (goat anti-mouse, alkaline phosphatase conjugated) was applied for $90 \mathrm{~min}$ (1:1000 dilution), washed once in TBS, and placed in a developing solution containing NBT ( $p$-nitroblue tetrazolium chloride) and BCIP (5-bromo-4-chloro-3-indolyl phosphate). Protein bands developed between 30 and $60 \mathrm{~min}$. The blot was then stored in deionized water until analysis. Densitometric analysis of developed slot blots was performed using an Enprotech scanner and software. Data are expressed as mean units (relative amounts) of hsp $70 \mu^{-1}$ protein \pm the standard error of the mean (SEM). Units are the sample density divided by the reference sample density per microgram of protein (Cruz-Rodríguez \& Chu 2002).

Diagnosis of Perkinsus marinus (Dermo) infection: Prevalence and intensity of $P$. marinus infection in oysters were determined using total body burden assessment (Choi et al. 1989, Bushek et al. 1994). Oyster tissue was weighed and mechanically homogenized in $0.1 \mathrm{M}$ sodium phosphate buffer (Ultraturrax). A $1.0 \mathrm{ml}$ tissue aliquot was incubated in alternative fluid thioglycollate medium (AFTM) for 5 to $7 \mathrm{~d}$ at $20^{\circ} \mathrm{C}$. Tissue suspensions were then centrifuged at $800 \times g$ for $10 \mathrm{~min}$. Tissue pellets were re-suspended in $2.0 \mathrm{M}$ $\mathrm{NaOH}$ and incubated overnight at $60^{\circ} \mathrm{C}$. Tissue pellets were washed, centrifuged and re-suspended in distilled water. Aliquots of $100 \mu \mathrm{l}$ from each sample were added to a 96-well plate and stained with 1 to 2 drops of Lugol's solution (1:9 dilution). Stained P. marinus cells were counted under an inverted microscope at $400 \times$ magnification. Results are expressed as the log of the number of $P$. marinus cells $\mathrm{g}^{-1}$ wet tissue weight (ww).

Statistical analyses. Perkinsus marinus infections were compared by ANOVA between Dermochallenged and -unchallenged oysters (DC vs. UC), sublethally heat-shocked and non-sublethally heat-shocked oysters (HS vs. N), and over time $(0,2,7$ and $14 \mathrm{~d})$.

Proportional survival data were arcsine-square-root transformed and analyzed by ANOVA for effects of heat treatment (heat-shocked vs. non-heat-shocked oysters; HS vs. N), infection status (Dermo-challenged vs. -unchallenged oysters; DC vs. UC) and their interactions. In addition to ANOVA, mortalities were compared by survival analysis using the product-limit (Kaplan-Meier) method (Cox \& Oakes 1980, Newman 1994). Analysis was performed using the LIFETEST procedure in SAS. This procedure calculates log-rank and Wilcoxon statistics, which test if time-to-death is the same for each treatment.

Units of hsp70 isoforms and Perkinsus marinus infection data were log transformed to meet assumptions of normality and homogeneity of variance. Because of the 
presence of infected oysters in the UC treatments (see 'Results; Experimental infections with Perkinsus marinus'), infected individuals from these treatment groups were pooled statistically with the DC oysters, which had $100 \%$ prevalence of infection, and were designated as infected (I) oysters for hsp70 analyses. For hsp70 data, treatments were then designated as follows: (1) HS + I (sublethally heat-shocked, infected oysters, (2) N + I (non-sublethally heat-shocked, infected oysters, (3) HS + UI (sublethally heat-shocked, uninfected oysters and (4) N + UI (non-sublethally heat-shocked, uninfected oysters). Hsp70 data were analyzed by repeatedmeasures ANOVA for the factors treatment (HS or N), infection status (I or UI), day $(0,2$, 7 and $14 \mathrm{~d}$ post sublethal heat shock) and their interactions. Infection status and aquaria sampled over time in each treatment were treated as a within-subjects random factor. To examine the effect of infection levels on heat shock protein expression, body burden counts were classified into 4 categories: 0 (negative for $P$. marinus infection), 1 (1 to $10^{2}$ cells g $\left.{ }^{-1} \mathrm{ww}\right), 2\left(10^{3}\right.$ to $10^{4}$ cells $\left.\mathrm{g}^{-1} \mathrm{ww}\right)$ and $3\left(10^{5}\right.$ to $10^{6}+$ cells $\left.\mathrm{g}^{-1} \mathrm{ww}\right)$. The effect of infection level on hsp70 isoform expression was analyzed by ANOVA, with infection level as a random factor.

\section{RESULTS}

\section{Experimental infections with Perkinsus marinus}

Crassostrea virginica oysters experimentally challenged with $P$. marinus had mean $( \pm$ SEM) infection densities of $7.76 \times 10^{3}( \pm 0.70)$ cells g ${ }^{-1}$ ww $60 \mathrm{~d}$ after inoculation of freshly isolated $P$. marinus meronts. $P$. marinus infection was also detected in UC oysters, but infections were significantly lower than in DC oysters ( $\mathrm{p}<0.0001, \mathrm{n}=93$ ) (Fig. 1). Prevalence of infection among UC oysters was $32.7 \%$, and mean infection densities were $9.23 \pm 0.84$ cells $\mathrm{g}^{-1}$ ww over the course of the experiment. Prevalence among the DC oysters was $100 \%$, and mean infection densities were $6.38 \times$ $10^{4}( \pm 3.85)$ cells $g^{-1}$ ww. No significant changes in $P$. marinus infection were found in comparisons of sublethally heat-shocked versus non-sublethally heatshocked oysters (Fig. 2) or over time.

\section{Survival after lethal heat treatment}

Induced thermal tolerance was observed in oysters subjected to a sublethal heat shock (HS) $\left(40^{\circ} \mathrm{C}\right)$ prior to a lethal heat treatment (LHT) of $44^{\circ} \mathrm{C}$. Survival was significantly elevated in HS treatments compared to non-HS $(\mathrm{N})$ treatments (ANOVA, $\mathrm{p}=0.013, \mathrm{n}=3$ to 4

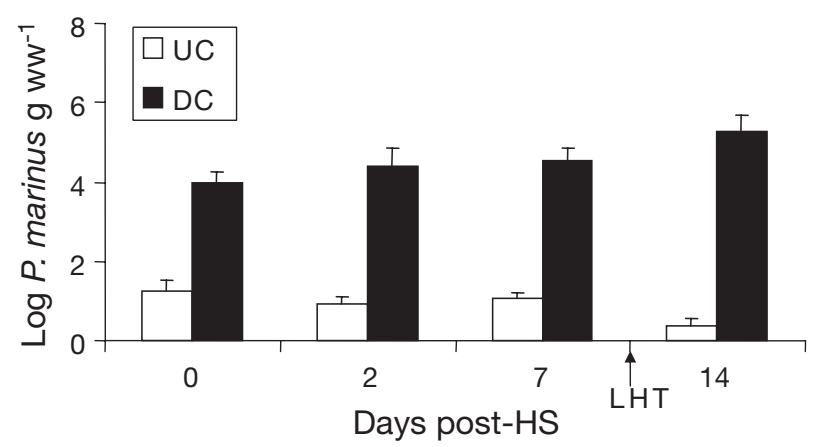

Fig. 1. Perkinsus marinus infecting Crassostrea virginica. Burden (log of the number of $P$. marinus cells $\mathrm{g}^{-1}$ wet tissue weight [ww] $\pm \mathrm{SEM}_{i} \mathrm{n}=93$ oysters per treatment) in Dermochallenged (DC) and -unchallenged (UC) oysters in relation to induced thermal tolerance. Oysters were subjected to a lethal heat treatment (LHT) for $1 \mathrm{~h}$ at $44^{\circ} \mathrm{C}$, immediately after the Day 7 sampling. P. marinus infection was evident in UC oysters, albeit at significantly lower levels than in DC oysters (ANOVA, $\mathrm{p}<0.0001$ ) HS: heat shock

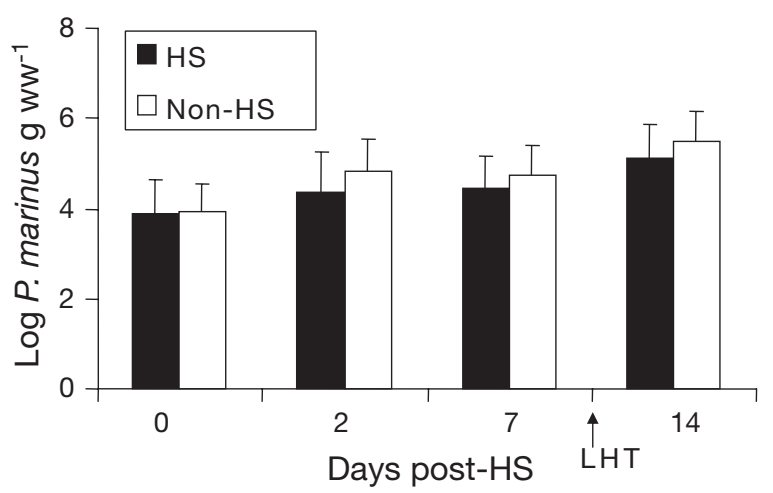

Fig. 2. Perkinsus marinus infecting Crassostrea virginica. Burden (log of the number $P$. marinus cells ${ }^{-1}$ wet weight [ww] \pm $\mathrm{SEM}_{i} \mathrm{n}=12$ ) in sublethally heat-shocked (HS) and nonsublethally heat-shocked (non-HS) oysters. A lethal heat treatment (LHT) was applied for $1 \mathrm{~h}$ at $44^{\circ} \mathrm{C}$

replicate tanks of 8 to 11 oysters each; total $n=138$ oysters. See Fig. 3 legend for specific n-values per treatment). Effects of Dermo challenge were not significant, and survival was similar between DC and UC oysters (Fig. 3).

Survival analysis also showed that sublethal heat shock significantly improved survival compared to survival in oysters that were not heat shocked (log-rank test, $\mathrm{p}<0.0001$; Wilcoxon test, $\mathrm{p}<0.0001$ ) (Fig. 4). Challenge status (either DC or UC treatments) did not affect survival after lethal heat shock. When survival data in DC and UC treatments were pooled statistically, sublethal heat stock (HS) significantly improved survival in oysters compared to oysters that were not sublethally heat stocked ( $\mathrm{N}$ treatment) (log-rank test, 


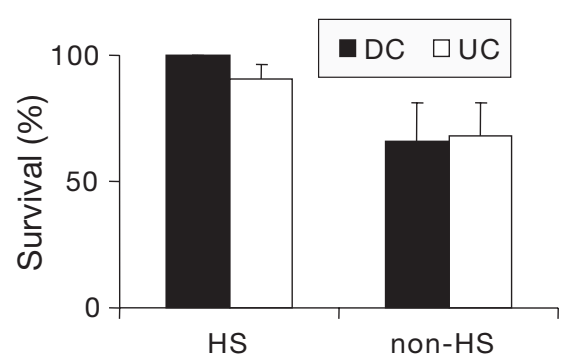

Fig. 3. Crassostrea virginica. Survival (\%) of oysters in sublethally heat-shocked (HS) and non-sublethally heat-shocked (non-HS), Dermo-challenged (DC) and -unchallenged (UC) oysters, $7 \mathrm{~d}$ after a lethal heat treatment of $44^{\circ} \mathrm{C}, 1 \mathrm{~h}$. Data shown are percent survival \pm SEM of 3 to 4 tanks per treatment, with each tank containing 8 to 11 oysters per tank. For HS + DC treatment: $\mathrm{n}=36$ oysters; non-HS + DC treatment: $\mathrm{n}=28 ; \mathrm{HS}+\mathrm{UC}$ treatment: $\mathrm{n}=30$; non-HS + UC treatment: $\mathrm{n}=44$. Effects of sublethal heat shock significantly enhanced survival (ANOVA, $\mathrm{p}=0.013$ ). Challenge treatments (DC or UC) did not significantly affect survival

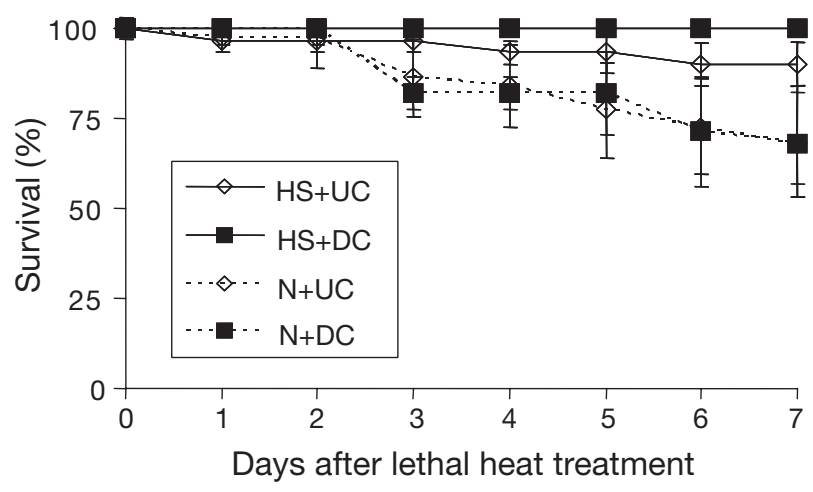

Fig. 4. Crassostrea virginica. Survival (mean \% survival/treatment \pm SEM at each day) in oysters over $7 \mathrm{~d}$ after a lethal heat treatment (LHT) of $44^{\circ} \mathrm{C}$ for $1 \mathrm{~h}$. HS + UC: sublethally heatshocked, unchallenged oysters; HS + DC: sublethally heatshocked, Dermo-challenged oysters; N + UC: non-sublethally heat-shocked, unchallenged oysters; N + DC: non-sublethally heat-shocked, Dermo-challenged oysters ( $\mathrm{n}=3$ to 4 tanks per treatment with 8 to 11 oysters per tank. For HS + UC treatment: $\mathrm{n}=30$; HS $+\mathrm{DC}$ treatment: $\mathrm{n}=36$ oysters; $\mathrm{N}+\mathrm{UC}$ treatment: $\mathrm{n}=44 ; \mathrm{N}+\mathrm{DC}$ treatment: $\mathrm{n}=28$. Time-to-death analyses resulted in $\mathrm{p}<0.0001$ for both log-rank and Wilcoxon tests

$\mathrm{p}=0.0002$; Wilcoxon test, $\mathrm{p}=0.0003)$. Sublethal heat shock also improved survival in DC oysters alone (log-rank test, $\mathrm{p}=0.033$; Wilcoxon test, $\mathrm{p}=0.035$ ). The effect of Dermo challenge within HS and $\mathrm{N}$ treatments was also compared. The effect of Dermo challenge was not significant, although a trend was apparent in HS oysters ( $p=0.054$ for both log-rank and Wilcoxon tests). In that comparison, DC oysters exhibited higher survival than UC oysters (100\% vs. $90.3 \pm$ $5.8 \%, \mathrm{n}=32$ to 44 for DC oysters and $\mathrm{n}=24$ to 33 for UC oysters).

\section{Hsp70 expression}

Western blot analyses showed variation in expression of the hsp70 isoforms. Two molecular weight isoforms were detected at 69 and $72 \mathrm{kDa}$, as previously described (Fig. 5 in the present study, Encomio \& Chu 2005). The $69 \mathrm{kDa}$ isoform (hsp69) increased significantly after sublethal heat shock ( $\mathrm{p}=0.0303$; Fig. 6A), and the levels of hsp69 increased over time, although not significantly ( $p=0.0718$; Fig. $6 \mathrm{~B}$ ). The increase of hsp69 over time accounted for most of the increase in total hsp70 over time, although the increase in total hsp70 was not significant. Levels of hsp69, however, did not significantly change with infection status (I or UI). Interactions between infection status and day were significant $(p=0.0495)$ in hsp69. Changes in hsp72 and total hsp70 were not significant, either due to heat shock, infection status, or day. Furthermore, infection levels (classified as 0, 1, 2, or 3; see 'Materials and methods; Statistical analyses') did not significantly affect the expression of either hsp isoform detected in the present study.

Although ANOVA did not detect significant differences due to sublethal heat shock or infection, there were apparent differences in isoform expression of hsp70 when comparing infected (combined HS and N oysters) and uninfected (combined HS and N) treatments separately. Among infected oysters hsp69 increased over time in non-sublethally heat-shocked (N) oysters (Fig. 7A). At Day 14, levels of hsp69 in the N + I group were similar to those of the HS + I oysters, although this was not surprising as these were the oysters that survived the LHT. In uninfected oysters hsp69 was higher in sublethally HS individuals up to Day 7 , and it decreased $7 \mathrm{~d}$ after LHT (Day 14) (Fig. 7B). Expression of hsp69 also increased with time (up to $7 \mathrm{~d}$ ) in the N + UI oysters. Overall expression of hsp72 occurred less frequently and at lower levels than that of hsp69. At Day 0, when oysters were sampled to measure hsp70 immediately after sublethal heat shock and

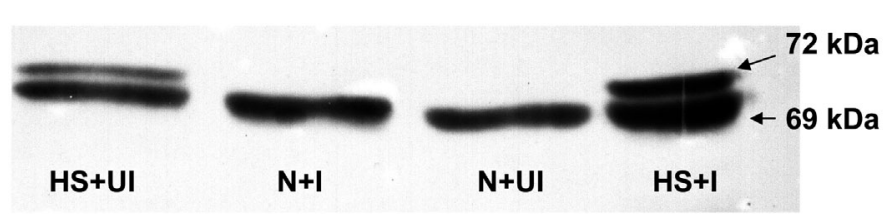

Fig. 5. Crassostrea virginica. Western blot showing expression of hsp70 isoforms (hsp69 and hsp72) in oysters. Samples shown are representative of 4 different treatments, i.e. HS + UI: sublethally heat-shocked, infected oysters; N + I: non-sublethally heat-shocked, infected oysters; $\mathrm{N}+\mathrm{UI}$ : non-sublethally heat-shocked, uninfected oysters; HS + I: sublethally heat-shocked, infected oysters. Uninfected or infected oysters denote actual infection status regardless of whether oysters were initially challenged with Perkinsus marinus or not 


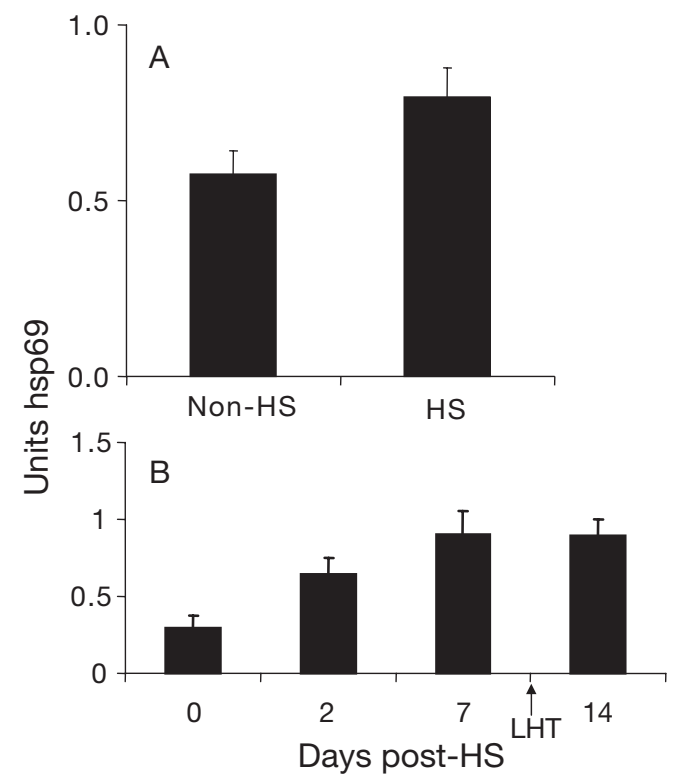

Fig. 6. Crassostrea virginica. (A) Units of hsp69 as analyzed by Western blots. Data presented are means \pm SEM, $n=61$ for sublethal heat shock (HS) and $n=52$ for non-sublethal heat shock (non-HS) treatments collapsed across effects of day and infection status. HS significantly elevated hsp69 over the levels in non-HS oysters (ANOVA, $p=0.0303$ ). (B) Changes in the hsp69 isoform 0, 2, 7 and $14 \mathrm{~d}$ post-HS. Data are presented as mean units of hsp69 \pm SEM ( $\mathrm{n}=13$ to 14 ) collapsed across factors of HS treatment and infection status. A lethal heat treatment (LHT) of $1 \mathrm{~h}$ at $44^{\circ} \mathrm{C}$ was administered immediately after the Day 7 sampling

infected oysters that were heat shocked had the highest levels of hsp72 (Fig. 8A). At Days 2 and 7 expression of hsp72 was similar between HS + I and N + I oysters (Fig. 8A). Expression of hsp72 was higher at Day 14 ( $7 \mathrm{~d}$ after LHT) in the HS + I oysters compared to the $\mathrm{N}+\mathrm{I}$ oysters. In UI oysters, sublethal heat shock increased expression of hsp72 (Fig. 8B). However, levels of hsp72 decreased at Day 14 in HS + UI oysters, while expression of hsp72 was very low in the $\mathrm{N}+\mathrm{UI}$ oysters overall, with hsp72 expression absent to nearly absent at Days 2 and 14 (Fig. 8B). Infection (I) alone appeared to have an effect on non-HS oysters $(\mathrm{N}+\mathrm{I})$ as expression of hsp72 was more frequent and at higher levels compared to N + UI oysters (Fig. 8A,B). A similar trend was seen in hsp69, but the differences between $\mathrm{N}+\mathrm{I}$ and $\mathrm{N}+$ UI oysters were slight (Fig. 7A,B).

\section{DISCUSSION}

Similar to a previous study (Chu \& Volety 1997), in the present study inoculation of Crassostrea virginica oysters with a dose of $\sim 1 \times 10^{6}$ freshly isolated meronts per oyster resulted in $100 \%$ prevalence with moderate

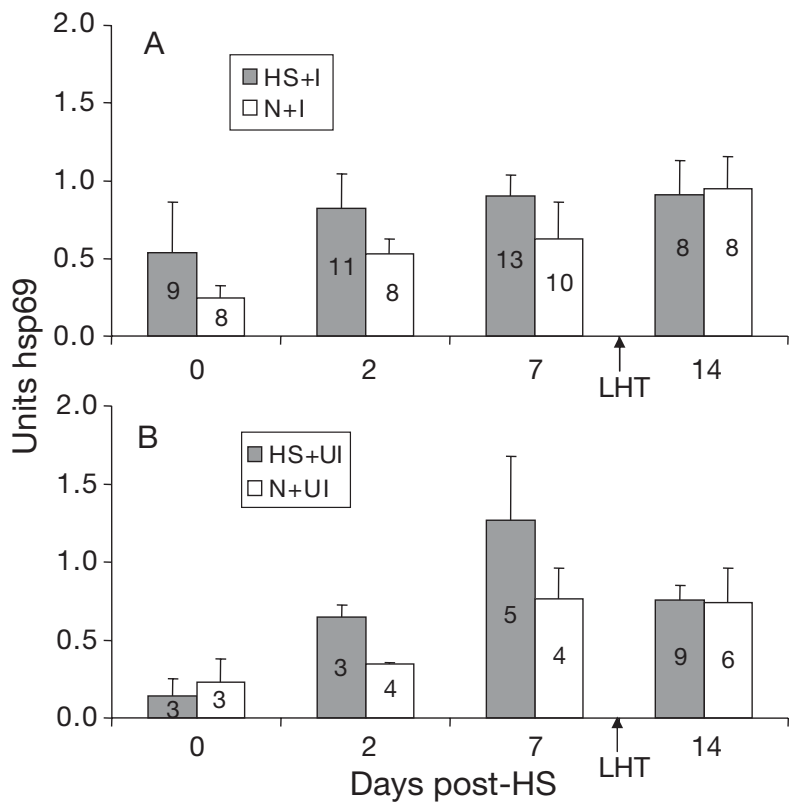

Fig. 7. Crassostrea virginica. (A) Levels of hsp69 at 0, 2, 7 and $14 \mathrm{~d}$ after sublethal heat shock (post-HS) in sublethally heatshocked (HS + I) and non-sublethally heat-shocked $(\mathrm{N}+\mathrm{I})$ oysters infected with Perkinsus marinus. (B) Levels of hsp69 in uninfected sublethally heat-shocked (HS + UI) and nonsublethally heat-shocked $(\mathrm{N}+\mathrm{UI})$ oysters at $0,2,7$ and $14 \mathrm{~d}$ post-HS. Data are presented as mean units of hsp69 \pm SEM (n-values for each treatment are shown within their respective bar). A lethal heat treatment (LHT) of $1 \mathrm{~h}$ at $44^{\circ} \mathrm{C}$ was administered immediately after the Day 7 sampling

to high infections in oysters after $60 \mathrm{~d}$. Light infections found in the unchallenged treatment groups likely originated from Maine. The Ray tissue assay (Ray 1966) used for the initial screening of Perkinsus marinus infection is less sensitive than the body burden assay and has been cited as being prone to false negatives at light infection levels (Bushek et al. 1994). Although infections in Maine oysters are still rare, the northward extension of $P$. marinus has been documented and is likely currently occurring (Ford 1996). The infections found in the unchallenged oysters were unlikely to have caused much physiological stress. Calculations estimate that the energy budget of an oyster is only significantly impacted by moderate to very high $P$. marinus infections (Choi et al. 1989).

A sustained, elevated expression of heat shock proteins after exposure to acute thermal stress is an almost universal characteristic of the heat shock response (Lindquist 1986, Lindquist \& Craig 1988, Feder \& Hofmann 1999). The length of the response may be dependent on the severity of the heat stress (Lindquist 1986). In Crassostrea virginica, we observed that total hsp70 remained elevated in gill tissues for 2 to $4 \mathrm{wk}$ after heat shock (Encomio 2004, Encomio \& Chu 2004). 


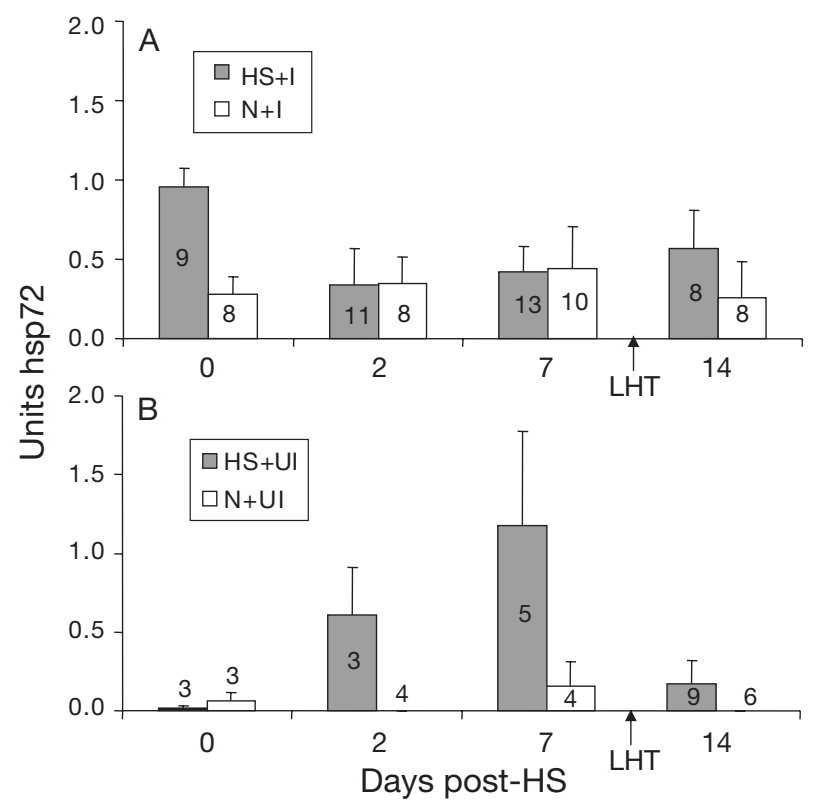

Fig. 8. Crassostrea virginica. (A) Levels of hsp72 as analyzed by Western blot in sublethally heat-shocked (HS + I) and nonsublethally heat-shocked (N + I) oysters infected with Perkinsus marinus at 0, 2, 7 and $14 \mathrm{~d}$ post-HS. (B) Levels of hsp72 in uninfected sublethally heat-shocked (HS + UI) and nonsublethally heat-shocked ( $\mathrm{N}+\mathrm{UI})$ oysters at $0,2,7$ and $14 \mathrm{~d}$ post-HS. A lethal heat treatment (LHT) of $1 \mathrm{~h}$ at $44^{\circ} \mathrm{C}$ was administered immediately after the Day 7 sampling, as shown in both (A) and (B). Data are presented as mean units of hsp72 \pm SEM ( $\mathrm{n}$ values for each treatment are shown within their respective bar). Bars that are not visible denote means either close to or at 0 units hsp72

This also occurred in C. gigas and the flat oyster Ostrea edulis, in which elevated levels of hsp70 persisted for 2 wk (Clegg et al. 1998, Piano et al. 2002). In several bivalve species increased levels of heat shock proteins are seen after a distinct period of time ( 48 to $96 \mathrm{~h}$ after heat shock). This occurred in the mussels Mytilus edulis and in several species of oysters, e.g. C. gigas, O. edulis and C. virginica (Tirard et al. 1995, Chapple et al. 1997, Clegg et al. 1998, Cruz-Rodriguez \& Chu 2002, Piano et al. 2002). During the period of increased hsp70 levels, thermal tolerance is enhanced. Pre-treatment of $M$. edulis with high temperature resulted in increased heat resistance after $3 \mathrm{~d}$, and induced thermal tolerance was highest $2 \mathrm{~d}$ after heat shock in $C$. gigas (Huppert \& Laudien 1980, Clegg et al. 1998). The elevated expression of hsp70 in C. gigas was associated with an enhanced thermal tolerance that lasted up to $14 \mathrm{~d}$ (Clegg et al. 1998). In the present study we showed that a sublethal heat shock improved tolerance to thermal stress in $C$. virginica for at least $7 \mathrm{~d}$, with increased survival in HS oysters. The implication for elevation of hsp70 and thermal tolerance is that both eastern and Pacific oysters can resist multiple bouts of thermal stress over prolonged periods. Although the reasons for sustained elevation of heat shock proteins are unknown, but it is speculated that heat shock may disrupt protein synthesis and thus the mechanisms controlling the regulation of hsp synthesis, resulting in reduced turnover of heat shock proteins (Hochachka \& Somero 2002). Additionally, hsp70 mRNA may be stable for several days (Hofmann 1999).

The present study demonstrated that sublethal heat shock improved thermal tolerance in Crassostrea virginica, in a manner similar to C. gigas (Shamseldin et al. 1997, Clegg et al. 1998, Hamdoun et al. 2003). Initially, it was expected that Perkinsus marinus infections would increase susceptibility to lethal heat stress. In oysters infected with Haplosporidium nelsoni, acute elevation of temperature from 20 to $30^{\circ} \mathrm{C}$ increased oxygen consumption and ammonia production compared to that in uninfected oysters, implying that diseased oysters were more susceptible to heat stress (Littlewood \& Ford 1990). Challenge with the bacterium Nocardia reduced thermal tolerance in C. gigas (Friedman et al. 1999). Other parasites, such as trematodes, reduce the resistance of gastropods to extreme changes in temperature and salinity (Lauckner 1980). In the present study, however, infection did not reduce thermal tolerance. The level of protection conferred by sublethal heat shock may have overridden any deleterious effects of infection on thermal tolerance. The sublethal heat shock temperature also may have affected function in $P$. marinus. Heat treatments of $40^{\circ} \mathrm{C}$ and higher for 30 min reduced the viability of cultured $P$. marinus (Soudant et al. 2005). High temperatures that oysters are capable of withstanding may limit the growth of $P$. marinus. Infection did not reduce condition, as there were no differences in the condition index between infected and uninfected oysters (data not shown). Physiological condition in oysters is only significantly reduced in advanced infections (Dittman et al. 2001). Infection intensities did reach levels $\left(10^{4}\right.$ to $10^{5}$ cells $\mathrm{g}^{-1} \mathrm{ww}$ ) that would be expected to affect oyster physiology. However, physiological effects of $P$. marinus infection have been difficult to demonstrate, and are strongly influenced by season, environment and reproductive state (Craig et al. 1989, Newell et al. 1994, Dittman et al. 2001, Encomio et al. 2005).

As shown previously (Encomio \& Chu 2005), hsp isoform expression varied and was not identified strictly as inducible (hsp69) or constitutive (hsp72), as demonstrated in previous studies (Clegg et al. 1998, Piano et al. 2002, Boutet et al. 2003, Hamdoun et al. 2003, Brown et al. 2004). In the present study, hsp69 was expressed in a constitutive manner, and was present in almost all samples of all treatments. Differences in hsp69 between treatments were due to an increase in levels, and not induction of expression, which implies 
de novo synthesis of this isoform. Furthermore, hsp69 was predominantly expressed over hsp72 (Figs. 5, 7 \& 8). Differences in patterns of hsp70 expression between our study and previous studies may be due to differences in antibody specificity. The antibody clone (7.10, Affinity Bioreagents) used in other studies recognized 3 isoforms of hsp70 (69, 72 and $77 \mathrm{kDa})$, with the $69 \mathrm{kDa}$ isoform characterized as inducible upon sublethal heat shock (Clegg et al. 1998, Piano et al. 2002, Boutet et al. 2003, Hamdoun et al. 2003, Brown et al. 2004). Although the antibody used (Clone 3A3, Affinity Bioreagents) in the present study recognized a $69 \mathrm{kDa}$ isoform, it is possible this isoform is still different from the inducible isoform identified in the preceding studies (Clegg et al. 1998, Piano et al. 2002, Boutet et al. 2003, Hamdoun et al. 2003, Brown et al. 2004). Although similar in molecular weight, isoforms may have different isoelectric points, resolvable only by 2dimensional electrophoresis. If hsp69 is more heat sensitive, predominant expression may be a result of using Maine oysters in our experiments, which would be expected to be more sensitive to temperature than Chesapeake Bay oysters. Control temperatures in our experiments (20 to $22^{\circ} \mathrm{C}$ ) approach the maximal aquatic temperatures $\left(25^{\circ} \mathrm{C}, \mathrm{C}\right.$. Davis, Pemaquid Oysters, pers. comm.) that Maine oysters experience in their native habitat.

Infection with Perkinsus marinus may have also contributed to the increase in hsp72 in both heat-shocked and non-heat-shocked oysters. Pathogens can induce expression of heat shock proteins in various host species. Levels of hsp70 increased in livers and kidneys of coho salmon Oncorhynchus kisutch when artificially infected with Renibacterium salmonarum (Forsyth et al. 1997). House martins Delichon urbica parasitized by triatonid bugs and trypanosomes had increased levels of hsp60 in their blood (Merino et al. 1998). The nematode Trichinella spiralis induced elevated expression of hsp25 and hsp70 in rats (Martinez et al. 1999). The increase in hsp72, however, was not indicative of an increase in thermal tolerance, as non-sublethally heat-shocked ( $\mathrm{N}$ treatments) oysters experienced greater mortalities than those that were heat shocked, regardless of differences in heat shock protein expression. The increase in hsp72 observed in infected oysters may not substantially contribute to thermal tolerance and may be an indicator of stress, but not stress resistance. Additionally, heat shock protein expression and thermal tolerance are not always tightly coupled (Easton et al. 1987). Other heat shock proteins and other mechanisms, such as changes in membrane fluidity may contribute to thermal tolerance.

In previous studies we demonstrated that the heat shock response can be sustained for $>2$ wk (Encomio 2004, Encomio \& Chu 2004). Prolonged over-expres- sion of heat shock proteins may be indicative of how long oysters can remain tolerant to stress, and whether that resistance can be artificially enhanced. The present study shows that sublethal heat shock improved survival in oysters. Thermal tolerance was enhanced, even in oysters infected with Perkinsus marinus, showing that the heat shock response was not negatively affected by disease. This is important as heat shock could be utilized as a way to improve survival in diseased oysters. Techniques to harden animals, such as intertidal culture, are often employed to improve survival of oysters and reduce fouling (Ventilla 1984, Handley \& Bergquist 1997). An understanding of the heat shock response and its role in thermal and pathogenic stress is important to improve survival in cultured bivalves.

Acknowledgements. This research was supported by the NOAA-Sea Grant Oyster Disease Research Program (Project VA-OD-01-05) to F.L.E.C. The views expressed herein are those of the authors and do not necessarily reflect the views of the NOAA or any of its subagencies. The authors thank E. Lund and G. Constantin for technical assistance. Special thanks are given to J. Shields and S. Shumway for constructive reviews of earlier drafts of this manuscript. This paper represents Contribution No. 2844 from the Virginia Institute of Marine Science, College of William and Mary.

\section{LITERATURE CITED}

Andrews JD (1965) Infection experiments in nature with Dermocystidium marinum in Chesapeake Bay. Chesap Sci 6: $60-67$

Andrews JD (1988) Epizootiology of the disease caused by the oyster pathogen Perkinsus marinus and its effects on the oyster industry. In: Fisher WS (ed) Disease processes in marine bivalve molluscs, Vol 18. American Fisheries Society, Bethesda, MD, p 47-63

Bosch TCG, Krylow SM, Bode HR, Steele RE (1988) Thermotolerance and synthesis of heat shock proteins: These responses are present in Hydra attenuata but absent in Hydra oligactis. Proc Natl Acad Sci USA 85:7927-7931

Boutet I, Tanguy A, Rousseau S, Auffret M, Moraga D (2003) Molecular identification and expression of heat shock cognate 70 (hsc70) and heat shock protein 70 (hsp70) genes in the Pacific oyster Crassostrea gigas. Cell Stress Chaperones 8:76-85

Brown HM, Briden A, Stokell T, Griffin FJ, Cherr GN (2004) Thermotolerance and HSP70 profiles in adult and embryonic Californian native oysters, Ostreola conchaphila (Carpenter, 1857). J Shellfish Res 25:135-141

Burreson EM, Ragone-Calvo LM, La Peyre JF, Counts F, Paynter KT (1994) Acute osmotic tolerance of cultured cells of the oyster pathogen Perkinsus marinus (Apicomplexa: Perkinsada). Comp Biochem Physiol A 109:575-582

Bushek D, Ford SE, Allen SK Jr (1994) Evaluation of methods using Ray's fluid thioglycollate medium for diagnosis of Perkinsus marinus infection in the eastern oyster, Crassostrea virginica. Annu Rev Fish Dis 4:201-217

Calvo LMR, Calvo GW, Burreson EM (2003) Dual disease resistance in a selectively bred eastern oyster, Crassostrea 
virginica, strain tested in Chesapeake Bay. Aquaculture 220:69-87

Chapple JP, Smerdon GR, Hawkins AJS (1997) Stress-70 protein induction in Mytilus edulis: tissue-specific responses to elevated temperature reflect relative vulnerability and physiological function. J Exp Mar Biol Ecol 217:225-235

Choi KS, Wilson EA, Lewis DH, Powell EN, Ray SM (1989) The energetic cost of Perkinsus marinus parasitism in oysters: quantification of the thioglycollate method. J Shellfish Res 8:125-131

Chu FLE, La Peyre JF (1993) Perkinsus marinus susceptibility and defense-related activities in eastern oysters Crassostrea virginica: temperature effects. Dis Aquat Org 16: 223-234

Chu FLE, Volety AK (1997) Disease processes of the parasite Perkinsus marinus in eastern oyster Crassostrea virginica: minimum dose for infection initiation, and interaction of temperature, salinity and infective cell dose. Dis Aquat Org 28:61-68

Clegg JS, Uhlinger KR, Jackson SA, Cherr GN, Rifkin E, Friedman CS (1998) Induced thermotolerance and the heat shock protein-70 family in the Pacific oyster Crassostrea gigas. Mol Mar Biol Biotechnol 7:21-30

Cox DR, Oakes D (1984) Analysis of survival data. Chapman and Hall, New York

Craig A, Powell EN, Fay RR, Brooks JM (1989) Distribution of Perkinsus marinus in Gulf Coast oyster populations. Estuaries 12:82-91

Cruz-Rodriguez L, Chu FLE (2002) Heat shock protein (HSP70) response in the eastern oyster, Crassostrea virginica, exposed to PAHs sorbed to suspended artificial clay particles and to suspended field contaminated sediments. Aquat Toxicol 60:157-168

Dittman DE, Ford SE, Padilla DK (2001) Effects of Perkinsus marinus on reproduction and condition of the eastern oyster, Crassostrea virginica, depend on timing. J Shellfish Res 20:1025-1034

Easton DP, Rutledge PS, Spotila JR (1987) Heat shock protein induction and induced thermal tolerance are independent in adult salamanders. J Exp Zool 241:263-267

Encomio VG (2004) A study of the eastern oyster, Crassostrea virginica. 1. Dermo tolerance, survival, growth, condition and hsp70 expression in different geographic stocks. 2 . Heat tolerance and effects of sublethal heat shock on survival and hsp70 expression of infected and uninfected oysters. PhD dissertation, The College of William and Mary, Williamsburg, VA

Encomio V, Chu FLE (2004) Characterization of heat shock protein expression and induced thermotolerance in $P$. marinus parasitized oysters: lab and field studies. J Shellfish Res 23:289

Encomio VG, Chu FLE (2005) Seasonal variation of heat shock protein 70 in eastern oysters (Crassostrea virginica) infected with Perkinsus marinus (Dermo). J Shellfish Res 24:167-175

Encomio VG, Stickler SM, Chu FLE (2005) Performance of 'natural Dermo-resistant' oyster stocks: survival, disease, growth, condition and energy reserves. J Shellfish Res 24: 143-155

Feder ME, Hofmann GE (1999) Heat shock proteins, molecular chaperones, and the stress response: evolutionary and ecological physiology. Annu Rev Physiol 61:243-282

Fisher WS, Gauthier JD, Winstead JT (1992) Infection intensity of Perkinsus marinus disease in Crassostrea virginica (Gmelin, 1791) from the Gulf of Mexico maintained under different laboratory conditions. J Shellfish Res 11:363-369 Ford SE (1996) Range extension by the oyster parasite Perkin- sus marinus into the northeastern United States: response to climate change? J Shellfish Res 15:45-56

Forsyth RB, Candido EPM, Babich SL, Iwama GK (1997) Stress protein expression in coho salmon with bacterial kidney disease. J Aquat Anim Health 9:18-25

Friedman CS, Cherr GN, Clegg JS, Hamdoun AH, Jacobsen JL, Jackson SA, Uhlinger KR (1999) Investigation of the stress response, summer mortality and disease resistance of oysters, Crassostrea spp. J Shellfish Res 18:297

Gething M, Sambrook J (1992) Protein folding in the cell. Nature 355:33-45

Gupta RS, Golding GB (1993) Evolution of HSP70 gene and its implications regarding relationships between archaebacteria, eubacteria and eukaryotes. J Mol Evol 37:573-582

Hamdoun AM, Cheney DP, Cherr GN (2003) Phenotypic plasticity of HSP70 and HSP70 gene expression in the Pacific oyster (Crassostrea gigas): implications for thermal limits and induction of thermal tolerance. Biol Bull (Woods Hole) 205:160-169

Handley SJ, Bergquist PR (1997) Spionid polychaete infestations of intertidal Pacific oysters Crassostrea gigas (Thunberg), Mahurangi Harbour, northern New Zealand. Aquaculture 153:191-205

Hochachka PW, Somero GN (2002) Biochemical adaptation. Oxford University Press, New York

Hofmann GE (1999) Ecologically relevant variation in induction and function of heat shock proteins in marine organisms. Am Zool 39:889-900

Huppert HW, Laudien H (1980) Influence of pretreatment with constant and changing temperatures on heat and freezing resistance in gill-epithelium of the mussel Mytilus edulis. Mar Ecol Prog Ser 3:113-120

Kleinschuster SJ, Parent J (1995) Sub-clinical infection of oysters (Crassostrea virginica, Gmelin, 1791) from Maine by species of the genus Perkinsus (Apicomplexa). J Shellfish Res 14:489-491

La Peyre JF (1996) Propagation and in vitro studies of Perkinsus marinus. J Shellfish Res 15:89-101

Lauckner G (1980) Diseases of Mollusca: Gastropoda. In: Kinne O (ed) Diseases of marine animals, Vol 1. Biologische Anstalt Helgoland, Hamburg, p 311-324

Lindquist S (1986) The heat-shock response. Annu Rev Biochem 55:1151-1191

Lindquist SC, Craig EA (1988) The heat shock proteins. Annu Rev Genet 22:631-677

Littlewood DTJ, Ford SE (1990) Physiological responses to acute temperature elevation in oysters, Crassostrea virginica (Gmelin, 1791), parasitized by Haplosporidium nelsoni (MSX) (Haskin, Stauber, and Mackin, 1966). J Shellfish Res 9:159-163

Lowry OH, Rosenbrough NJ, Farr AL, Randall RJ (1951) Protein measurement with the folin phenol reagent. J Biol Chem 193:265-275

Martinez J, Perez Serrano J, Bernadina WE, RodriguezCaabeiro F (1999) Influence of parasitization by Trichinella spiralis on the levels of heat shock proteins in rat liver and muscle. Parasitology 118:201-209

Mears HC (1993) Oyster disease research (ODR) program. J Shellfish Res 12:351-368

Merino SMJ, Barbosa A, Moller AP, De Lope F, Perez J, Rodriguez-Caabeiro F (1998) Increase in heat shock protein from blood cells in response of nestling house martins (Delichon urbica) to parasitism: an experimental approach. Oecologia 116:343-347

Morimoto RI, Tissieres A, Georgopoulos C (1990) The stress response, function of the proteins and perspectives. Stress Prot Biol Med 1:1-35 
Newell RIE, Paynter KT, Burreson EM (1994) Physiological effects of protozoan parasitism on the eastern oyster Crassostrea virginica: feeding and metabolism. J Shellfish Res 13:294

Newman MC (1994) Quantitative methods in aquatic ecotoxicology. CRC Press, Boca Raton, FL

Piano A, Asirelli C, Caselli F, Fabbri E (2002) Hsp70 expression in thermally stressed Ostrea edulis, a commercially important oyster in Europe. Cell Stress Chaperones 7: $250-257$

Ray SM (1966) A review of the culture method for detecting Dermocystidium marinum, with suggested modifications and precautions. Proc Nat Shellfish Assoc 54:55-69

Sanchez EH, Lindquist SL (1990) HSP 104 required for induced thermotolerance. Science 248:1112-1115

Sanders BM (1988) The role of stress protein response in physiological adaptation of marine molluscs. Mar Environ Res 24:207-210

Editorial responsibility: Richard Cawthorn,

Charlottetown, Prince Edwards Island, Canada
Shamseldin AA, Clegg JS, Friedman CS, Cherr GN, Pillai MC (1997) Induced thermotolerance in the Pacific oyster, Crassostrea gigas. J Shellfish Res 16:487-491

Soudant P, Chu FLE, Lund ED (2005) Assessment of the cell viability of cultured Perkinsus marinus (Perkinsea), a parasitic protozoan of the eastern oyster, Crassostrea virginica, using sybrgreen-propidium iodide double staining and flow cytometry. J Eukaryot Microbiol 52(6):492-499

Tedengren M, Olsson B, Reimer O, Brown DC, Bradley BP (1999) Heat pretreatment increases cadmium resistance and HSP 70 levels in Baltic Sea mussels. Aquat Toxicol 48: $1-12$

Tirard CT, Grossfeld RM, Levine JF, Kennedy-Stoskopf S (1995) Effect of hyperthermia in vitro on stress protein synthesis and accumulation in oyster haemocytes. Fish Shellfish Immunol 5:9-25

Ventilla RF (1984) Recent developments in the Japanese oyster culture industry. Adv Mar Biol 21:1-57

Submitted: August 1, 2006; Accepted: May 20, 2007

Proofs received from author(s): June 29, 2007 